\title{
Disaster Politics: Cyclone Politicking and Electioneering in the Kingdom of Tonga
}

\section{Abstract}

Entering the new year of 2014 the Kingdom of Tonga had enough to worry about; a local economy choking to near death and a finance minister sacked and replaced in a political spectacle leaving the public baffled over what went wrong between him and the Prime Minister (Fayle, 2014; Lopeti, 2014c; Fonua, 2014b). People uttered they looked forward to the end of year election tentatively set for Thursday November 27 th. The 2010 register of around forty thousand voters had increased at the 2014 intake by four thousand, mostly voters who had turned the age of suffrage at twenty one years old. The chorus call from the masses was simple, vote them out. Then Cyclone Ian struck on Saturday 11 January 2014 aggravating Tonga's money shortage.

Journalist Pesi Fonua wrote "the impact on the Tongan economy of the cyclone and the salary rise for civil servants at this point of time is a matter of great concern" (Fonua, 2014a). He was right. The state and taxpayers could not afford economic recovery from Tonga's cruellest cyclone, a symptom of climate change, let alone paying for a $5 \%$ rise in the cost of living allowance for public servants. As the national debt distress sore became inflamed the Public Service Association decided it was the right time to fight cabinet for a $22 \%$ living allowance rise because 5\% was not enough (Lopeti, 2014a). This essay asks a pointed question. Leading up to the general

Teena Brown Pulu has a PhD in anthropology from the University of Waikato. She is a senior lecturer in Pacific development at AUT University. Her first book was published in 2011, Shoot the Messenger: The report on the Nuku'alofa reconstruction project and why the Government of Tonga dumped it. 
election of November 2014, how was cyclone politicking being manoeuvred to sway the way people would vote?

\section{Tonga disaster politics}

Cyclone Ian was rated at category 5, the severest tropical storm. Tonga's northern group Vava'u got battered around and bruised in a few places. In between Vava'u and the main island of Tongapatu lay Ha'apai, a group of 51 atolls with a total population of 6,616 which copped the rough end of the stick (Statistics Department of Tonga, 2013). Brutally bashed from the harshest climate hiding ever to hit Tonga, 1,094 homes and buildings on six islands spread across eighteen villages collapsed. North-eastern Ha'apai was described as "completely destroyed" with one cyclone-related death and fourteen others suffering minor injuries ('Aho, 2014; Television New Zealand, 2014b; Television Tonga, 2014c; United Nations, 2014b).

It was estimated that 2,335 Ha'apai people were left homeless and up to 5,000 were affected by a varying scale of loss of assets, livelihood, and quality of life (Braddock, 2014). A United Nations situation report projected that "950 farming households" were "in need of [humanitarian] assistance" (United Nations, 2014a). Nine days after the cyclone wreaked havoc, the Tongan government put out the call for international humanitarian assistance confessing it did not have "local expertise or resources" to cope on its own (Baines, 2014b; Radio Australia, 2014; United Nations Information Centre, 2014; World Bank, 2014a).

One lesson stood out from Cyclone Ian smashing into a dozen and a half villages on six of Tonga's low-lying atolls on the Saturday afternoon of January 11th 2014. Natural and political disaster can travel a volatile course hand-in-hand (Brown Pulu, 2013). On this matter, the stormy government to government relations between Tonga and New Zealand predetermined three political factors. Firstly, how the New 
Zealand government argued it could not help Ha'apai cyclone victims until the Tongan government asked for their help. Secondly, the nine day length of time that the Tongan state took to organise an initial request for outside assistance (Television New Zealand, 2014a). Notable here was the ambivalent manner in which Prime Minister Lord Tu'ivakano and Deputy Prime Minister Samiu Vaipulu officially asked New Zealand for help (Radio New Zealand, 2014d; Television Tonga, 2014j, 2014k, 20141).

Contrastingly, a month after the cyclone stuck Ha'apai, Tonga's deputy prime minister appealed outright to China for a cash donation to rebuild 17 damaged schools which were no longer useable. There was a striking political factor which became evident. Once the Tongan government's post-cyclone recovery plan headed by Samiu Vaipulu was given the green light at cabinet, the requests for monetary donations to rebuild Ha'apai housing and state infrastructure were manifold, costly, and levelled at China for the simple reason that Tonga and China's bilateral agreements held greater economic dependency than the present New Zealand relationship.

Put simply, China could be relied on to give a straight-cash donation for a national disaster operation with no conditions on how and where Tonga were to spend the gifted money (Brant, 2014; Matangi Tonga Online, 2014b; Television Tonga, 2014c, 2014d). New Zealand came at assistance from the opposite angle and could be expected to give goods and technical expertise, rather than money, with a list of stipulations on what they demanded in return from Tonga.

What we are seeking now is assistance from the donor partners to build transitional and permanent classrooms. We are targeting to request China for this assistance, but whoever will step in first to pledge their support, we will accept it. Government will be paying the fees of Ha'apai students and students from Ha'apai whom are studying here in Tonga. The sum will be 
paid by government emergency fund. World Bank also questioned the amount of money reserved in our emergency relief fund and I told them that people's needs which cannot be provided [for] due to the natural disaster, we'll use this money for it. We will use this amount but at the same time, we will look at ways to return that amount to the emergency relief fund (Samiu Vaipulu cited in Television Tonga, 2014d).

Thirdly and perhaps most significant, the politicking set-off by cyclone disaster led to a shifting alliance between Tonga's deputy prime minister Samiu Vaipulu and the New Zealand foreign minister Murrary McCully. Their association was not necessarily based on political alignment or economic dependency, but rather, a relationship of convenience coupled with the acquainted circumstance of playing traditional roles of the superior Western donor and an inferior Native recipient. Compounded by the fact that it was an election year in Tonga and New Zealand, McCully and Vaipulu manoeuvred around a multi-donor relief and recovery operation laced with a campaigning tactic. To separate out the politicians' electioneering from disaster management was difficult, and the question of whether the Tongan government's desire to rebuild 800 permanent homes destroyed by Cyclone Ian was feasible was never convincingly answered.

At a glance, the deputy prime minister looked as if he was Tonga's prime minister. Samiu Vaipulu headed the National Emergency Management Office (NEMO) under his Ministry of Infrastructure with a capped budget of under \$6 million Tongan pa'anga. He gave the official interviews for Radio and Television Tonga news. He signed donor agreements for recovery and rebuilding. He accepted public donations deposited to a Westpac account managed by the Ministry of Finance and National Planning. Lastly, he took control of what the government would and would not ship free of charge 
to Ha'apai as part of the national effort, and importantly, how the limited national relief fund would be spent.

Releasing the Government of Tonga's ambitious plan to collect \$59.7 million pa'anga or USD \$32.8 million American dollars from aid donors and banks to rebuild 800 temporary and permanent homes, Vaipulu stated that "if we have to borrow money then we would have to do that. But if it's for the sake of the people, I'd rather do it." (Pulu, 2014; Pacific Eye Witness, 2014). The likelihood that Tonga might take out a bank loan to rebuild two sets of housing, one transitional shelter and one permanent house for 800 properties, was fast becoming grim reality.

The World Bank in Sydney upped the numbers estimating a complete rebuild at USD \$50 million while donating USD \$1 million to repair the Ha'apai port, roads, and airport under an existing bilateral Tongan Government and Australian Government transport sector project. Money for housing as a "possible area of support" was the statement given by World Bank country director for the Pacific Islands, Franz DreesGross. However, this did not amount to a definite yes, the World Bank would meet the total sum Tonga wanted up front for 800 x 2 cyclone resistant abodes, which Vaipulu commented would be a temporary one standing alongside a permanent house (World Bank, 2014a; Television Tonga, 2014a).

The temporary abode which the Tongan government wanted to construct over a three month period was what the World Bank and the United Nations Office for the Coordination of Humanitarian Affairs politely nodded to in official communication. But to fork out for the entire gamut including 800 permanent homes at a total cost of $\$ 59.7$ million pa'anga, which Tonga's cabinet hoped to build in eighteen months on money the ministers assumed developed countries might give to them, sounded like pie-in-the-sky talk. 
I hope the government can build 50 houses and the rest of the 750 houses will wait for assistance from donor partners. The World Bank had agreed to cover the cost of 70 per cent of the transitional houses for Ha'apai residents. The remaining 30 per cent of the cost will depend on the Tongan government. After the work on temporary houses we continue on to permanent houses which will stand next to the temporary houses. The temporary houses will be built under the same plan and size and they will make sure that it can withstand future cyclones. (Samiu Vaipulu cited in Television Tonga, 2014a).

New Zealand's foreign minister Murray McCully called Samiu Vaipulu's estimate of $\$ 59.7$ million Tongan pa'anga "frightening," signalling his government was not altogether eager to pay the full price Tonga was pleading for (Pacific Eye Witness, 2014). McCully had put NZD \$1.4 million of New Zealand's total cyclone assistance totalling at NZD \$2.27 million into repairing the Ha'apai electricity network (New Zealand Government, 2014a; Matangi Tonga Online, 2014d). A calculated decision on the New Zealand Government's part, McCully promoted his energy portfolio.

During his term as Foreign Minister, he pushed New Zealand's state-owned company Meridian Energy for building solar farms in Tonga and the Pacific Islands. It had become his political strategy for marketing New Zealand companies to the region. Deploying Tongan "line mechanics" from Northpower Limited to work in Ha'apai as well as supplying generators and technical equipment meant cash payment for New Zealand companies (Northpower, 2014).

By no means did McCully's aid package straightforwardly amount to New Zealand aid providing income to the Tongan state-owned enterprise Tonga Power Limited or creating work for local businesses, suppliers, and technicians. In the aid 
business, New Zealand's fundamental interest was to safeguard its own economy.

What was the Tongan state's motive for publicly advocating a complete rebuild above and beyond the range and reach of its national budget? An outdated urban-drift ideology leaked out of the deputy prime minister's brainchild. By Samiu Vaipulu's rationale it was plainly undesirable to have Ha'apai cyclone refugees migrate to the main island of Tongatapu. Expressly, the overcrowded urban sprawl of Tonga's capital Nuku'alofa with squatter settlements of outer islanders growing in number on the eastern and western borders posed an urban development dilemma for town planning (Ewart, 2014).

Nuku'alofa had a land and housing shortage as well as sewage, waste management, water, flooding, and youth unemployment stressors for the state bureaucracy to contend with (Maclellan, 2014). A sharp population increase would turn up the resource pressure valve to high. But an irony prevailed in the sense that Tonga's deputy prime minister had been a people's representative for an outer island constituency of the Vava'u group for twenty five years.

Unwittingly, Vaipulu demarcated a social boundary. There were outer islanders like himself who were allowed to internally migrate to Tongatapu and gain access to land, state resources, and employment. Then there were others of a different class and kind who were denied the choice of internal migration by a Tongan state directive insisting they be confined to the nation's outliers (Dornan, 2014).

We want to ensure that the people of Ha'apai stay there and do not come to Tongatapu. We want to rebuild their homes and also the economy. Cabinet has approved the rehabilitation plan for the people of Ha'apai. We see that there is a need to have temporary shelter, which will be built first then the permanent homes, which we hope to have completed within 18 months. We do not want to see a repeat of what 
happened in the Niuas. We will be talking with donor governments and agencies to help us rebuild Ha'apai. (Tora, 2014).

In sobering detail, Samiu Vaipulu seemed quite prepared to deliberately increase national debt to over the sovereign threshold of 50\% GDP, which meant an incoming government might inherit a new debt legacy come November 2014. This raised the alarm as to whether the Tu'ivakano government had carefully considered that financially the move nailed the lid on the coffin of Tonga's new administration, whomever that might be, before they even started work. Who does that? Only in Tonga was the response from overseas Tongan spectators, a derogative slur indicating the speaker was rolling their eyes in disbelief at the flippancy of how the math was calculated and the numbers thrown out for public backers.

The Tu'ivakano cabinet's four-year stint as a more democratically elected government had left an unpleasant taste. Tongans in diaspora grew painfully aware that the homeland state floundered in crisis management redeploying from one disaster initiative to the next. Worse still, the Prime Minister had become infamous for reshuffling cabinet ministers and their portfolios like a deck of cards with a gambler's expectation that miraculously Tonga would get dealt the winning hand. Exerting short-term thinking that insufficiently grasped the long-term consequences of panicky ad hoc solutions was the government of the day's trademark. This government, it was said, survived hand-to-mouth and week-to-week with little consistency at balancing the books and struggling to keep a finance minister for a year, let alone a term.

\section{Aid breeds dependency}

If there was an origin moment when the mentality of aid dependency weighed down by bank loan debt got put into 
words then Samiu Vaipulu was the architect for the Tu'ivakano government (Andreou, 2014). Self-assuredly he declared in local and international media that he was all for both, aid and loans. Speaking to Karen Magnall of Radio New Zealand in May 2012, one month after the death of King George Tupou V and the assent to the throne of his youngest brother King Tupou VI, the deputy prime minister was definitely not mourning the country's bank loan debt to the EXIM Bank of China. The Vaipulu mentality was that Tonga is "not in debt." Rather, "Tonga is highly developing" (Magnall, 2012).

We don't have money to develop our economy so that in the future we don't always have to ask New Zealand and Australia for money. I'm not afraid saying that Tonga is highly in debt. I say, it's not in debt. Tonga is highly developing. (Magnall, 2012).

Another Vaipulu interview went down on media record a year later at the July 2013 regional gathering in Nadi, Fiji, of the Pacific Platform for Disaster Risk Management and the Pacific Climate Change Roundtable (Gero et al, 2013). The deputy prime minister gave his opinion on why he wanted an amalgamated ministry between Environment and Climate Change which was under Lord Ma'afu and his own National Emergency Management Office and the Tonga Meteorological Service. He could get "more funding, aid and help." Unmistakably this was "for the benefit of the country and its people;" that is, acquiring extra money from donors, bank grants, or from wherever this Tongan ministry which conflated climate with disaster could get the dollar figure they desired.

Vaipulu says three days of dialogue at the Joint Meeting of the 2013 Pacific Platform for Disaster Risk Management and Pacific Climate Change Roundtable in Fiji, he is contemplating the merger of the Environment, 
Climate Change, Tonga Meteorological and National Emergency Office into one ministry. Vaipulu says he will raise this proposal with the Prime Minister and Cabinet. "My reason to merge these divisions is to be able to gain more funding, aid and help. If these divisions are merged they could be able to work more closely together for the benefit of the country and its people," says Vaipulu. (Secretariat of the Pacific Regional Environment Programme, 2013).

Vaipulu's disaster legacy had an effect on the human psyche of Tongan government bureaucrats. The National Reserve Bank's newly appointed governor, Dr Ngongo Kioa, was anticipating "economic growth" to GDP (gross domestic product); millions of dollars pouring into Tonga from the World Bank, the Asian Development Bank, New Zealand Aid, Australian Aid, US Aid, and China. Cyclone assistance was arguably Tonga's biggest money-maker by way that the "reconstruction" work in the Ha'apai islands would, in theory, remunerate public servants as well as private sector companies and suppliers. Money in large quantities coming into the country "would stimulate growth," and that was the extent of the Reserve Bank governor's calculation and comprehension (Matangi Tonga Online, 2014a).

Measuring the social cost of destruction to wellbeing and livelihood caused by the cyclone in Ha'apai did not figure in the governor's GDP equation. He was about measuring real "growth," not the emotional kind that glues kinfolk, villages, and small low-lying islands together for three thousand years of human settlement history in Tonga (Matangi Tonga Online, 2014a). Local histories of outer islanders and the attachments they formed to their people and place of belonging was not valuable social capital in the government method of building community resilience to climate change. 
Cyclone Ian could be a blessing in disguise for Tonga's struggling economy, with the Reserve Bank now predicting an economic stimulation from the inflow of new development assistance. Dr Ngongo Kioa, the new Governor of Tonga's National Reserve Bank, said this week that he expected that the multi-million dollars assistance pledged by donors for the reconstruction of Ha'apai would stimulate Tonga's economic growth and increase the Gross Domestic Product (GDP). Speaking on the "State of the Tongan Economy" to members of the Tonga Chamber of Commerce on Monday February 24, Ngongo said that the irony of the situation was that a growth burst of the Tongan economy takes place during reconstruction after a major destruction. (Matangi Tonga Online, 2014a).

A colleague wrote me from Tongatapu with observations from Tongans living on the main island of the national relief operation in Ha'apai. The insights here were noted before the deputy prime minister announced the government would move into the recovery phase of appealing for donations to rebuild $800 \times 2$ temporary and permanent houses. One critical reflection shone like a light: "They see help no longer as a gift but a right."

Referring to Ha'apai cyclone victims, the speaker positioned local people in the present political climate of Tonga's aiddriven economy. By this, aid, assistance, donations, and the labour of others was perceived to be a form of entitlement that people duly expected as their "right," prerogative, and privilege. "Post-traumatic" stress was not counted out as a factor determining the dispiritedness of Ha'apai locals in being unmotivated to "clean up or work on their properties." (Anonymous Informant 1, 2014; Matangi Tonga Online, 2014c). However, this does not detract from the discussant's main emphasis: aid in the small island developing state of 
Tonga was now understood as a right, which held similar importance to a constitutionally guaranteed civil freedom.

The locals are not as involved in the clean up of their own places as they are leaving the clean up to people from the outside, the army, volunteers from Tongatapu, and from overseas. In fact if the locals were involved in the clean up, most of the rubbish would have been cleaned up by now. People are sitting around waiting for help, and very few are doing any clean up or work on their properties. This is so unlike Ha'apai people, but maybe they have changed. They see help no longer as a gift but a right. [Volunteers] are doing what the locals should be doing. The locals in the meantime are sitting around waiting for the tokoni [help]. I have heard it from different sources that this is a major issue observed by the visiting volunteers. The Free Wesleyans sent a team of faifekaus [ministers] to visit the affected areas, and they came back and announced that the Ha'apai affected people need counselling. I guess post-traumatic counselling. They may be right. (Anonymous Informant 1, 2014).

How far had the aid is entitlement syndrome infiltrated Tongan psychology? Undoubtedly the penetration was deep and multiplying in fertile conditions. John Pulu, a Tongan journalist for Television New Zealand's weekly show Tagata Pasifika, reported a Ha'apai update six-weeks after Cyclone Ian. Interview excerpts from Ha'apai women and men exemplified the emotional damage of having worldly possessions and homes smashed to pieces by natural disaster. Also evident was an unrealistic social expectation that the Tongan government and foreign donors would automatically rebuild homes for no cost to the consumer because this is what the locals considered they had a right to be given. 
I think maybe more than five or ten years to fix the house unless the government help us to build the house. ('Alisi 'Akau cited in Pulu, 2014).

We urgently need help right now so we can go back to our homes because the tents can't fit all our belongings. (Tevita Hiliau cited in Pulu, 2014).

Whatever entitlement people figured they deserved to compensate for their loss, the deputy prime minister was in the driver's seat, an authority of all state decisions on the Ha'apai situation (Television Tonga, 2014f). The destination he was driving the government to and dragging the country behind stirred a serious question. The answer, however, was evident in how Tonga's post-cyclone politics fell trap to an aid dependency mind-set fashioned by Samiu Vaipulu. Lord Tu'ivakano, the outgoing prime minister and an older generation noble came across hesitant and indecisive perched on the edge of a cyclone politicking led by Vaipulu. If anything, the Tongan public perceived the prime minister as going along for the ride of disaster business strategised by his deputy prime minister (Government of Tonga, 2014e).

\section{Bureaucracy of humanitarian assistance}

Back in New Zealand, Labour Party leader David Cunliffe was the opposition in the House. He thought that straight after Cyclone Ian struck the New Zealand government had offered "poor" humanitarian assistance to Tonga. Cunliffe scoffed that there was "an insufficient response to the cyclone crisis in Tonga." One cash donation to the Tongan government of NZD\$50,000 plus sending an RNZAF Orien to photograph the ground damage did not cut it. He was thinking around the one million dollar mark was reasonable in light that "Tonga is struggling to cope with the disaster and thousands of people in the Ha'apai island group are still displaced" (Radio New 
Zealand, 2014g). Why not a million cash up-front with no NZAID strings attached so the Government of Tonga was free to do as they wanted with the money according to their national disaster management plan and how they assessed their own people's needs?

Five days later, Tonga's deputy prime minister Samiu Vaipulu went through the New Zealand High Commission in Nuku'alofa, Tonga to formally ask for relief supplies. NZAID responded within 48 hours by creating a fund based at its Wellington headquarters valued at NZD $\$ 300,00$. There was a catch; only New Zealand non-government organisations such as Oxfam New Zealand and Red Cross New Zealand could bid for the cash to give out water and emergency kits in Ha'apai. On top of this, NZRAF flew to the main island of Tongatapu delivering evacuation tents, water, and some tools such as chainsaws and hammers on a Hercules C-130 considered too big to land directly on the Ha'apai airstrip. The supplies were then shipped from Nuku'alofa to Pangai wharf, adding an extra day to travel time.

Mana, a minority political party agreed with Labour. John Minto, a Mana candidate for Auckland edged the argument further by calling the National government's minimal response "an embarrassment" to New Zealanders (Minto, 2014; McCulloch, 2014). National's Minister of Pacific Island Affairs, Peseta Sam Lotu-Iiga, came back at Labour and Mana accusing them of playing politics and trying to score popularity points with voters (McCulloch, 2014). In the midst of Tonga's post-cyclone operation, Lotu-liga was made the National Party's first Samoan Minister of Pacific Island Affairs (Ministry of Pacific Island Affairs, 2014). It appeared the New Zealand government was also guilty of appealing to Pacific voters to kick off an election year of campaigning for power (Ministry of Pacific Island Affairs, 2014). Loto-Iiga had been appointed a minister by his party leader, New Zealand's Prime Minister John Key. Curiously, he stood outside of cabinet as the Minister of Pacific Island Affairs, which triggered criticism from 
Samoans in New Zealand that he was a token appointment, a puppet politician without voice and decision-making power inside his own cabinet (Kaniva Pacific, 2014).

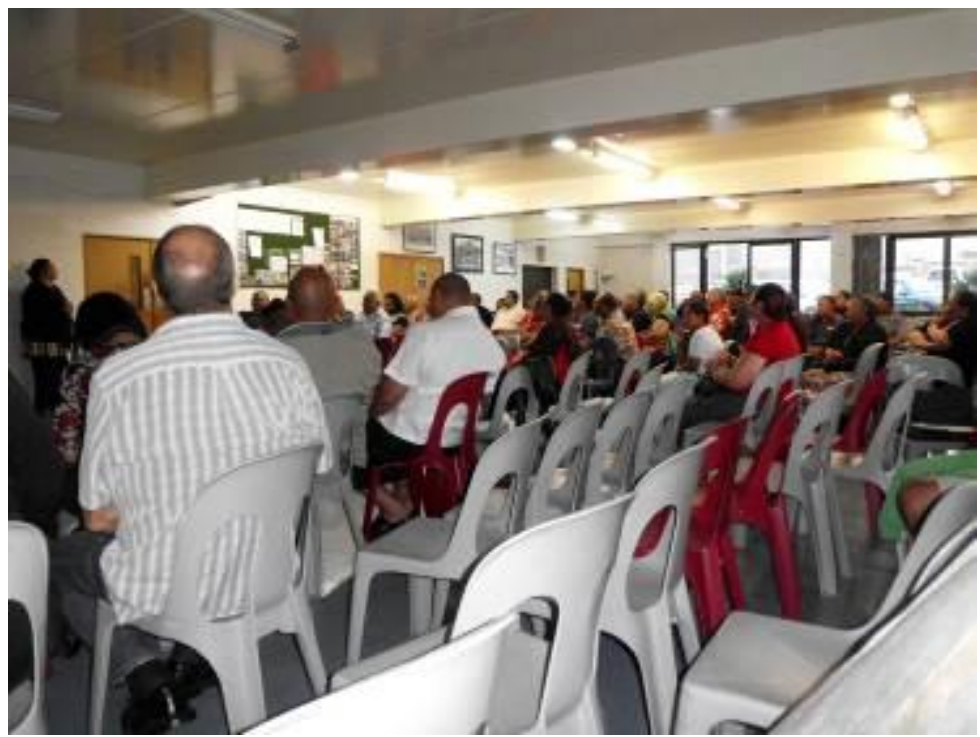

The public meeting to recruit a committee of volunteers to organise relief containers of food and water for Ha'apai cyclone victims at Lotofale'ia Methodist Church in Mangere, South Auckland.

On the evening of Tuesday January 14 at Lotofale'ia Methodist Church in Mangere, South Auckland, a public meeting was attended by approximately 50 women and men who were predominantly Tongan migrants with blood ties to the Ha'apai group. The purpose was to recruit volunteers for a Ha'apai Relief Committee tasked with collecting and packing relief goods in 20 feet containers donated by three shipping companies Pacific Direct Line, Matson, and Polynesian Shipping Line were transporting the freight from the Port of Auckland to the Port of Nuku'alofa on Tonga's main island free of charge. Drinking water, non-perishable food, pots, pans, 
and cutlery would go directly to families living on six cyclone effected islands across 18 villages. The displaced population who were homeless numbered at 2,335 people with a total of 5,000 people affected by cyclone damage to homes, properties, churches, shops, as well as public infrastructure such as roads, schools and the one hospital that served the Ha'apai group.

The front seats of the public meeting couched a political mix of National, Labour, and Mana Party representatives, along with Pacific members of the Auckland Mayoral Disaster Fund and one Palangi (white/European) reverend of the Anglican Church. These officials, either employed by the state or church clergy, were set up as the important speakers with each given a time-slot to address to audience. Seated behind them were the ordinary Tongans expected to fill up 44 gallon drums of donated goods named explicitly for their Ha'apai kinfolk.

From its inception, it was not clearly communicated if the relief effort was only for Ha'apai donors living in Auckland, or if food and water was also being collected from Tongans who had no blood tie to Ha'apai as well as the wider New Zealand public who were non-Tongan. The message was confusing and social media employed to mobilise support and gather donations, such as the Facebook page of the Ha'apai Relief Committee, looked and read like a charity drive exclusively for and by Ha'apai people. Understandably given this was an emergency exercise in collecting relief freight for cyclone victims, the core group targeted as donors were Aucklandbased families with kinship connections to, or land and property holdings in, the six affected Ha'apai islands.

Shipping relief containers by a family to family system where Auckland Tongans packed and named freight expressly for their kinfolk affected by natural disaster in Tonga had been done before. In 2002 when Cyclone Waka battered the Vava'u group, Auckland Tongans organised shipments of food and water by a family to family system, and again in 2009 when a 
tsunami hit Niuatoputapu, an island which at the time had a population of 934 people in Tonga's northern group. However, this time it was different by a heightened bureaucratisation of how humanitarian assistance crossed Tonga's border.

Although Cyclone Ian collected one life compared to the nine who died in Niuatoputopu's 2009 tsunami, it had wreaked the worst damage in Tonga's hurricane history to homes, buildings, boats, subsistence crops, and the state infrastructure of water, power and roads. The Ministry of Lands and Environment office based in Ha'apai estimated it would take ten years for the natural environment, particularly forestation and foreshores, to rejuvenate. Understandably, the amount of relief containers and the speed in which the senders wanted their freight to reach Ha'apai was greater than that of previous donations.

With this, came a social expectation that the New Zealand government and the Tongan government would work side-byside to foot the bill for customs tax and port dockage in Tonga, transhipping costs from Tongatapu to Ha'apai, and the handling and distribution of goods to Ha'apai families. But the relief system of Tonga's National Emergency Management Office was not straightforward.

Natural disaster preparedness plans of South Pacific nations and the responses of aid donor countries alongside humanitarian and monetary organisations and banks such as the United Nations, the World Bank, the Asian Development Bank, and the International Monetary Fund, were highly bureaucratised institutions. Local governments were integrated into international structures and processes. Climate change reinforced thick layers of red-tape in requesting international assistance and getting it to the Tongan state which in turn accounted for, checked, recorded what they got, and redistributed goods to village recipients. Containers of relief donated by Auckland Tongans got tangled up in tape. A trouble-free transfer of goods from an overseas community to homeland recipients did not take place. 
Instead, overseas donations were subjected to a governmental web of getting permission all the way up the state hierarchy; permission to get inside the Port of Nuku'alofa on Tonga's main island and further to Ha'apai by a domestic shipping route of 100 kilometres up the ocean highway (Australian Network News, 2014b). Three of the ten containers sent by Auckland Tongans were repacked and transhipped to Ha'apai from the Port of Nuku'alofa on Friday 7th of March. Staff from Pacific Forum Line's Tonga office volunteered the handling labour free-of-charge, and on the week of Monday 10th of March the goods were offloaded to Ha'apai families at Pangai wharf. A month to reach its destination was "too slow" by local opinion (Pulu, 2014).

I think it's too slow because we already get the donation from churches. I think the government, they are the first one to stand up and help their people, their country. (Siutaisa Tonga'onevai cited in Pulu, 2014).

The primacy of international stakeholders drove the bureaucratisation of national disaster management in the Pacific Islands and the way that humanitarian assistance from governments and inter-government organisations officially entered a developing country. Developed countries were protecting themselves against legal claims for loss and damage. By this, the World Bank bragged about awarding "the first Pacific catastrophic insurance payout [of USD \$1.27 million] to Tonga to help the country recover from Cyclone Ian" (Australia Network News, 2014). But this was an insurance company cough-up that Tonga had paid for as part of a pilot scheme for Pacific Island nations (Australian Network News, 2014a; Baines, 2014a; Government of Tonga, 2014d; World Bank, 2014b).

Under no uncertain means did an insurance policy entertain the dangerous idea that a small poor country like Tonga should, and could, use international law to sue the world's 
biggest polluter countries for the loss and damage they had inflicted on small island developing states. Why would they? The logic here was that small island developing states got enough of a settlement plus humanitarian aid to maintain their complacency over litigating for climate damages. But how did such high-level scheming impact on overseas communities and their charity donations?

In an interview with Radio Australia's Bruce Hill, Melino Maka, chair of the Tongan Advisory Council in Auckland, New Zealand, spoke candidly (Hill, 2014a, 2014d). He criticised the Tongan government's National Emergency Management Office headed by the deputy prime minister for charging distribution costs on four containers out of ten donated by New Zealanders to Ha'apai cyclone victims. Filled with non-perishable food and water, six containers were transferred by the Tongan state from the Port of Nuku'alofa to Pangai free-of-charge. The last four collected a fee of around TOP $\$ 2,000$ which the Ha'apai Relief Committee, a group of volunteers without funds to draw on was instructed to pay.

Maka's argument was based on principle. Given the container contents were charity and the senders of the cyclone assistance unpaid volunteers, why would the Government of Tonga bill them for vital supplies needed to supplement the national relief effort? Lusia Latu, a Tongan national living and working in Tonga posted an incisive commentary on my Facebook page which echoed and evoked Melino Maka's sentiments.

How can a government make money out of charity, out of the genuine giving of their own people for love, out of generosity for our people - Tonga people for Tonga people? It is already costing those GIVERS money to purchase, donate, and having to ship them to Ha'apai. OK, that's cool but you GIVERS also have to pay us for simply just watching you doing great things for Tonga. 
Now pay or no containers - to atu 'etau ngaue pule'anga ee - classic act! (Latu, 2014).

\section{Short play: Scene 1: New Zealand Tongans versus Tongan government}

Bruce Hill:

Melino Maka:

Bruce Hill:

Melino Maka:

Now this is the Tonga government is actually asking you, the Tongans in New Zealand, to pay not only for the containers full of goods but to actually pay for their distribution?

Yes, yes. But we have our own committee members on the ground helping with the distribution of food that we've already sent there with those six containers. But I think they were talking about the last four containers.

Are you in a financial position to be able to pay for the distribution of these goods that you've donated as well?

I don't think it's the issue about financial position because the committee don't have any money. But it's the issue that it's a personal view, I feel that we actually committed to the whole thing from the outset and the idea that we, my belief that it's a partnership between New Zealand and Tonga and with the community. But to ask the community to try to front up with money, I think it's a bit hard to follow. This is my own perspective. This is the first time in all the years that I [have been] involved in relief that I've been asked to actually pay for the stuff that we organised from this end. 
Bruce Hill:

Melino Maka:
Why do you think the Tongan government made that request from you?

Oh I think it's a reality now that they are really pressed for resources and the only way to do is to ask us to help out which is fine on one hand, but I think the principle of it, you know. We don't have money. We actually have committed a huge amount of our time to coordinate this relief effort. (Melino Maka cited in Bruce Hill, 2014a).

\section{Disaster is an electioneering strategy}

Some New Zealand academics were quick to interpret the real politick at play. Pakeha (white/European) sociologist Scott Hamilton did not hold fire: New Zealand government was straight-up stingy. This was not without rich country justification as to why Tonga, a poor country neighbour got the cold shoulder. Tonga's attention on China as its closest friend and development partner turned New Zealand icy. Hamilton thought New Zealand's foreign minister Murray McCully was still sore with Tonga's deputy prime minister Samiu Vaipulu getting his government a gifted plane from China (Hamilton, 2014). The problem with Vaipulu's plane was that it put Tonga's domestic flight service, a New Zealand company called Chathams Pacific, out of business. Chathams said it could not compete with a Tongan government plane flown by a Tongan company, and so packed up and went home, complaining it was hard done by.

Of course McCully retaliated because he could. He held the NZAID purse strings. It made minimal difference if the New Zealand government was led by National or Labour because an established relationship pattern had gelled with the Tongan government. New Zealand was the traditional donor and 
Tonga was the indebted recipient. But the Tu'ivakano regime, where the Prime Minister of Tonga himself was the Minister of Foreign Affairs, had turned into an ungrateful beneficiary of a traditional arrangement by getting into bed with China and practically breaking off the engagement with New Zealand.

McCully's Ministry of Foreign Affairs and Trade issued a travel advisory for New Zealanders on transport safety in Tonga (Radio New Zealand, 2013a, 2013b). The New Zealand government warning against the Chinese aircraft gifted to the Tongan government rang loud and clear (New Zealand Government, 2013).

Tonga's domestic airline fleet currently includes an MA60 aircraft. This aircraft has been involved in a significant number of accidents in the last few years. The MA-60 is not certified to fly in New Zealand or other comparable jurisdictions and would not be allowed to do so without a thorough certification process under Civil Aviation rules. Travellers utilising the MA-60 do so at their own risk. (New Zealand Government, 2013).

The upshot to all of this was that New Zealand travellers to Tonga intending to fly on the domestic airline could not readily get health and travel insurance with holiday packages. Insurers withdrew their customer service predicting the MA-60 aircraft gifted from China posed a burdensome business risk. The straw that broke the camel's back, however, was McCully's suspension of NZAID funding promised to the Tongan government to build the tourism sector into a regional competitor (Arrow, 2013; Hill, 2014). An aid dependent economy with a fledgling tourism industry that relied on New Zealand travellers as staple income, the double loss of NZAID's monetary injection and tourists was crippling. Tonga tourism virtually fell over (Radio New Zealand, 2014b).

Adding weight to a broke economy stressed by cyclone recovery was the fact it was an election year for both 
countries. The New Zealand and Tongan governments were on their way out, but not without a no holds barred mentality to how they did business. Bluntly, the Prime Minister Tu'ivakano and Deputy Prime Minister Vaipulu did as they pleased with Tonga's affairs, often recklessly and without thought as to how their impulsive decisions would cripple the country financially and politically long after they had been voted out of office. And McCully appeared to fall trap to their tactics, reacting like an old colonial administrator from the era of Empire set on disciplining and punishing the Natives into model behaviour as subordinates to New Zealand by his imperialist standards (Radio New Zealand, 2014a).

In the midst of Tonga's 2014 hurricane season a change of events blew in. New Zealand ex-patriate Shane Walker, a tourism operator in Vava'u and board member of the Tonga Tourism Authority, made a startling comment to Radio New Zealand journalist, Alex Perrottet. Walker suggested that a deal had been cut between the governments of New Zealand and Tonga (Radio New Zealand, 2014a, 2014b). They were to settle the dispute over the safety of the MA60 aircraft that China had gifted Tonga by a mediator. The International Civil Aviation Organisation was involved in "a [safety] certification process ... that's acceptable to New Zealand." Indeed this was "good news for Tonga," stated Walker; his voice showing optimism that his own tourism trade in Vava'u would be back in business. (Perrottet, 2014).

I was told recently, as late as Friday [21 February 2014] last week by some New Zealand Government officials that ICAO, the International Civil Aviation Organisation, has been looking closely at it. And I can't verify this exactly but reading between the lines, it's my understanding that everyone has agreed to do the work required to appease New Zealand's concerns and we're optimistic that a certification process will be put in place 
that's acceptable to New Zealand, so it should be good news for Tonga. (Shane Walker cited in Perrottet, 2014).

Walker's claim was immediately dropped by the official government-to-government circle. McCully declined to comment for New Zealand, and the International Civil Aviation Organisation felt "it wouldn't be appropriate for it to get involved in a long-standing dispute between Tonga and New Zealand." (Radio New Zealand International, 2014a).

An international civil aviation group says it wouldn't be appropriate for it to get involved in a long-standing dispute between Tonga and New Zealand. A member of Tonga's Tourism Authority, Shane Walker, says he was told the International Civil Aviation Organisation may have stepped in to solve the stand-off, but the organisation has distanced itself from the comments. (Radio New Zealand International, 2014a).

Most bewildering was the Government of Tonga's denunciation of Radio New Zealand for running a series of three news items unravelling Walker's assertion that a MA60 aircraft safety arrangement had been agreed to (Tonga Daily News, 2014). Deputy Prime Minister Samiu Vaipulu took to Television Tonga News on the evening of February 26th to put across his side of a tangled story. "I didn't realise he would make these terrible lies on the news," scorned Vaipulu, rebuking Alex Perrottet, the Radio New Zealand journalist who interviewed Shane Walker and pursued the story further by calling the deputy prime minister for a comment.

The truth was Shane Walker had speculated to media that Tonga was now in tow with New Zealand not the journalist, and Vaipulu was not necessarily discrediting his discussion as falsehood. What riled Tonga's deputy prime minister was the reporting angle where New Zealand's public broadcaster claimed that "Samiu Vaipulu has been adamant he won't ask 
a New Zealand technician to accredit the plane because it would offend the Chinese donors" (Radio New Zealand, 2014b). Reporting consistency was perceptible in Radio New Zealand's archive. On July 11th 2013, an interview excerpt from Murray McCully was broadcasted and published where New Zealand's foreign minister stated explicitly that "I've been offering to fund aviation safety expertise to go to Tonga [but] that's not an offer they had been prepared to accept" (Radio New Zealand, $2013 b)$. Vaipulu's retort published a couple of weeks later on July 25th was that "New Zealand should take any issues it has with the safety of the aircraft to China, not Tonga" (Radio New Zealand, 2013a).

SAMIU VAIPULU: The most simple thing is for McCully to contact the government of China and ask them if it is a faulty airplane. Why would they give it as a gift to Tonga? We have built our billboards, we have started our TV programmes in New Zealand - we're not stopping.

Murray McCully says Tonga has rejected an offer to help with safety issues and Mr Vaipulu has been pushing to get the Chinese plane.

MURRAY MCCULLY: I've been offering to fund aviation safety expertise to go to Tonga if that would assist in dealing with the issue. That's not an offer they had been prepared to accept, so we are really in their hands. (Radio New Zealand, 2013b).

Samiu Vaipulu says New Zealand should take any issues it has with the safety of the aircraft to China, not to Tonga. He says he is not worried about the suspension of [eight million US dollars] funding, saying it mainly affects New Zealand business people trying to sell their goods in Tonga. (Radio New Zealand, 2013a). 
A political driver was put into words from Vaipulu's outburst on Television Tonga News. The scuffle between him and McCully transpiring almost a year ago over the China gifted MA60 aircraft had shifted to a diplomatic patch-up between the New Zealand and Tongan governments. For what reasons, Tonga's deputy prime minister was not willing to discuss publicly, saying that "it's something that we [Mcully and I] agreed that we won't go into the media until we get things done."

What he did reveal was that a secret squirrel sign-off had taken place between the Government of Tonga and the New Zealand High Commissioner to Tonga, Mark Talbot. "McCully has kept his word," exclaimed Vaipulu on Tongan public television. He had "released part of the funds" from the USD \$8 million dollar aid package to Tonga's tourism industry, which previously he withheld due to what McCully originally maintained was an unsafe Chinese aircraft posing a risk to New Zealand tourists flying domestically from Tongatapu to the outer islands.

Why was a New Zealand Aid deal done on the sly by the High Commission to Tonga without an official press release by the Ministry of Foreign Affairs and Trade informing New Zealand taxpayers of where, how, and for what purpose had the state's money been spent on foreign aid? For a former settler colony of the British Empire with a large indigenous Maori and Pacific Islander population that politically asserted itself as a paternalistic neighbour to Pacific Island states, what is the point of preaching on democratic institutions to Tonga when the very principles of public transparency and accountability are not practiced by the New Zealand government? What did Vaipulu mean by saying he and McCully "won't go into the media until we get things done." What "things" and why secretive?

Kalolaine Tongalava: Tonga did not oppose a New Zealand expert from inspecting the MA60 
Anasiu Falekaono: $\quad$ The Honourable Deputy Prime Minister

aircraft, according to information released on Radio New Zealand International or RNZI this morning. This was confirmed to Radio Tonga News by the Honourable Deputy Prime Minister who is also the Minister for Infrastructure, Samiu Vaipulu. Samiu Vaipulu told Radio and Television Tonga this morning that the information released on Radio New Zealand International [is] untrue. This is [in] regard to the issue of assistance [from] New Zealand worth eight million US dollars.

Samiu Vaipulu:

No, there was no such comment from me. They called me from Radio New Zealand International, and I told them that I had a gentleman's agreement with Honourable Murray McCully and I'll respect that agreement, and I'm not giving anything to the media. Maybe they can call me in two or three weeks' time; maybe by then we have done something. But any other comments they made is false.

Anasiu Falekaono: Meanwhile, the Honourable Deputy Prime Minister says he has not given out any information to Radio New Zealand International regarding the MA60 aircraft issue.

Samiu Vaipulu: It's something that we agreed that we won't go into the media until we get things done. However, he has released part of the funds and it's already been signed between the 
[Tongan] government and the [New Zealand] High Commissioner here. So McCully has kept his word and I don't know what the media is trying to do. And I am still keeping my word. I'm not releasing anything until I talk with $\mathrm{Mr}$ McCully again. It is with due respect, the media should stay and report things according to what's been said, instead of trying to make problems between countries. Even the person that called me yesterday, I'm sorry I forgot his name, because I didn't realise that he would make these terrible lies on the news.

Anasiu Falekaono: [The] Honourable Deputy Prime Minister believes inaccurate information may mislead the public's attention and affect the diplomatic relationship between the Tongan government with its foreign counterpart. (Samiu Vaipulu cited in Television Tonga, 2014a).

There were traces of an electioneering strategy in Murray McCully's turnaround on retracting the USD \$8 million promised to Tonga's tourism industry. Samiu Vaipulu had made a pertinent point: New Zealand's withdrawal of aid "mainly affects New Zealand business people trying to seek their goods in Tonga" (Radio New Zealand, 2013a). 


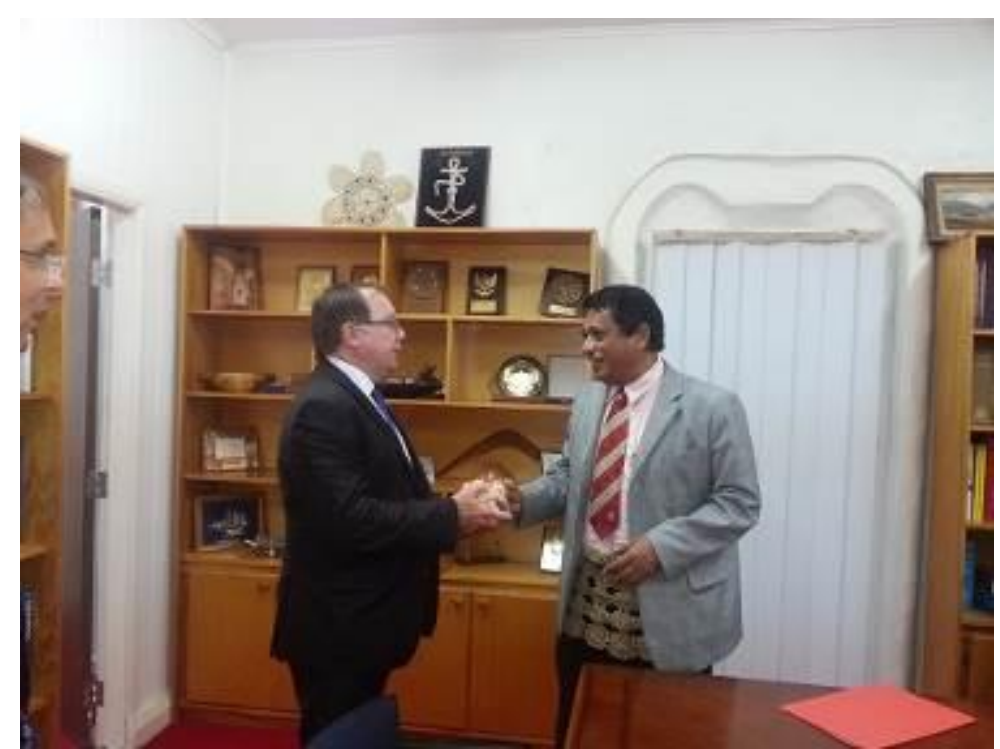

New Zealand foreign minister Murray McCully shaking hands with Tonga prime minister Lord Tu'ivakano at the prime minister's office in Nuku'alofa. Photograph by the Ministry of Information and Communications, Government of Tonga.

Shane Walker was one of a cluster of New Zealand ex-patriates who had set themselves up as tourism operators in Tonga. The local industry was dominated by New Zealand business people, all Pakeha (white/European). Moreover, the newly appointed general manager of Tonga Tourism Authority Stuart Perry was an older generation white Australian male (Government of Tonga, 2014a). How could small Tongan businesses compete equitably in a tourism sector where white foreigners constituted the authority?

It was not singly the aftermath of a category 5 cyclone in Ha'apai that prompted McCully to have a change-of-heart over his China aircraft disgruntlement. Rather, the New Zealand Foreign Minister was carefully campaigning towards an October election in which his government of two terms, 
amounting to six years, was not convincingly picked at the polls to win. Vaipulu operated under a similar circumstance. He assured Ha'apai cyclone victims there would be a complete rebuild of 800 permanent homes in eighteen months; not that his government had the money in hand, but none-the-less, it was priming up to be a November election of donor pledges and politicians' promises. Consequently, the row about the China aircraft got toned down because making up and remaining on friendly terms with the neighbour was more politically expedient than brawling over the fence.

Radio New Zealand's contention that "Samiu Vaipulu has been adamant he won't ask a New Zealand technician to accredit the plane because it would offend the Chinese donors" was sidestepped by Vaipulu (Radio New Zealand, 2014b). Apart from commenting to Television Tonga that "Tonga did not oppose a New Zealand expert from inspecting the MA60 aircraft," the China question remained unanswered. Would China be offended at the way Tonga conducted back-room business by getting Murray McCully to release "part of the [USD \$8 million] funds" he had withdrawn in exchange for a safety certification arrangement that appeased the New Zealand government? (Television Tonga, 2014a).

Observably, the electioneering strategies of these New Zealand and Tongan government ministers converged to capitalise on disaster. Here, McCully and Vaipulu played out an old donor and recipient scene where New Zealand came to poor Tonga's rescue and answered requests for help as their closest developed country neighbour. During the New Zealand foreign minister's two-day visit to Nuku'alofa from January 31 st to February 1st, he discussed disaster relief efforts as well as the Tonga and New Zealand joint commitment for development authorised by the New Zealand Aid programme (Government of Tonga, 2014b; New Zealand Aid, 2011; New Zealand Government, 2014a, 2014b, 2014c, 2014d). A press conference was given by Samiu Vaipulu and Murray McCully at the National Emergency Management Office which focused 
entirely on New Zealand's assistance to the proposed Ha'apai rebuild (Government of Tonga, 2014a; New Zealand Aid, 2011). Tonga's deputy prime minister wept on camera, wiping his tears with his handkerchief. Overcome with emotion he expressed to McCully, the New Zealand government, and the New Zealand High Commissioner to Tonga, Mark Talbot, "You have been with us all along and it's much appreciated" (Matangi Tonga, 2014d). Television Tonga reported that McCully's sentiments were clear-cut: "New Zealand will always be on Tonga's side to provide any assistance needed" (Television Tonga, 2014e). While Matangi Tonga published an excerpt from McCully's speechmaking emphasising that the MA60 China aircraft skirmish was somewhat mended in light of urgency for Ha'apai's cyclone recovery.

The Deputy PM and I may have some different views on the best way forward there, but we are good friends and we are in constructive dialogue on the best longterm arrangement for both the transport and marine safety here. We haven't really focused on that issue this trip as the immediate requirement is to focus on Ha'apai. (Murray McCully cited in Matangi Tonga, 2014d).

Tongan media had unambiguously read McCully's dialogue in black-and-white with no shades of grey changeability. By this, how easily could a New Zealand Aid package impose concessions on Tonga's part, reversing their bilateral relationship with China back to favouring the West? New Zealand's foreign minister was taken to have made a very specific pledge; that is, the New Zealand government would be financially willing and able to bankroll the cash and goods required to help complete an eighteen month elaborate and costly plan to rebuild $800 \times 2$ temporary and permanent abodes in Ha'apai. 
Was there any reason why his discussion might not be interpreted this way? Tongans were desperate to have the uncertainty surrounding the living conditions for Ha'apai cyclone victims resolved by a definite vote of confidence that there was adequate money to rebuild 800 permanent homes and lives. McCully was a seasoned politician. Calculatingly he played to a captive audience of social anguish to win the advantage for the New Zealand government in being needed by Tonga. Trapped in the neediness of a distraughtly poor country, Tonga's bargaining power with New Zealand becoming immediately transformed into a characteristic South Pacific scene: the Native dependant and white paternalism, charity, and benevolence (Television Tonga, 2014g, 2014h).

In terms of the cyclone recovery there are some things we can do within the existing programme, but I want to be quite clear the cyclone recovery funds will be on top of the funds normally committed to Tonga in the coming year. (Murray McCully cited in Matangi Tonga, 2014d).

Considering that the New Zealand foreign minister's visit and statements led the local media to believe he was unquestionably behind the Tongan government's proposed rebuild, which was provisional and subject to funding or a bank loan, it was understandable that Television Tonga News had a slant they pitched to viewers. McCully and New Zealand were the hero. A government of predominantly white New Zealand men who upheld conservative-right politics had flown to Tonga's side to save the day.

Fatai Fainga'a:

The Honourable New Zealand Foreign Minister Murray McCully is on a twoday visit to Nuku'alofa to assist Tonga's recovery activities in the Ha'apai group of islands. While speaking to the media, one of the 
Murray McCully:

Fatai Fainga'a:

Murray McCully: issues raised was the reconstruction of permanent housing for the residents of Ha'apai.

The deputy prime minister's just given me some very frightening figures in terms of the cost of reconstruction of houses. That is obviously something that is going to require multi-donor effort and we'll have some further discussions to work out how New Zealand can best contribute to that process.

The Foreign of New Zealand Honourable Minister Murray McCully also commended the hard work and good leadership role taken by the deputy prime minister Honourable Samiu Vaipulu, especially on helping those who were severely affected by the tropical Cyclone Ian in the Ha'apai group of islands. He also elaborated that New Zealand will always be on Tonga's side to provide any assistance needed.

People in New Zealand watched very closely as the cyclone struck Ha'apai. In fact, it was so slow there was intense interest in the build-up and track of the cyclone. And so we were able to send an Orien P3 to do quick reconnaissance work but we've been in good communication with the Tongan government to do what we can to render assistance, and now we're focused very much on the recovery. We've been impressed in New Zealand 
to see strong and firm leadership as is always required in these difficult situations. We are very keen to be of assistance. (Murrary McCully cited in Television Tonga, 2014e).

In the storyline Television Tonga invented an interlude of quite significant considerations by Samiu Vaipulu was downplayed. Here, the deputy prime minister admitted at the press conference with McCully that this is "what we [cabinet] are thinking of doing" (Television Tonga, 2014e; Tora, 2014). There was no definite plan set in stone with verifiable funding to rebuild two sets of 800 temporary and permanent homes for Ha'apai cyclone victims at all. In reality cabinet had accepted aspirational ideas that it hoped to pursue if the recommended rebuild was in any way financially achievable (Radio New Zealand, 2014c; Television Tonga, 2014b). Whether it would get done according to plan was by no means unequivocally known.

We need the people of Ha'apai to move from tents to some kind of temporary [shelter] during that transitional period [which] would be three months. That's what we are thinking of doing and for permanent houses maybe eighteen months from now. (Samiu Vaipulu cited in Television Tonga, 2014e).

\section{Silencing the opposition}

From the opposition bench, the leader of Tonga's Democratic Party 'Akilisi Pohiva had an axe to grind about the Tongan government's disaster performance. At seventy two years old, Pohiva was campaigning for prime minister after failing to secure the head of government job the first time around at the 2010 election. In an interview with Radio Australia's Bruce Hill, he condemned the state's post-cyclone effort early on in 
the piece for not showing "New Zealand and Australia" equal amounts of gratitude for their relief donation compared to the big fuss made over China (Hill, 2014b, 2014c; Government of Tonga, 2014f, 2014g; Prime Minister's Office, 2014; Lopeti, 2014b).

China had only arrived on "the scene ... maybe 10 years ago," said Pohiva. Scathingly he thought "it's shameful" behaviour on Tonga's part because the "Commonwealth countries" were Tonga's enduring friends (Hill, 2014b). Pohiva made it no secret that his loyalty was to the old-guard Commonwealth countries of New Zealand and Australia. In turn, these countries were strategic allies to the United States of America. New Zealand and Australia assumed responsibility for policing the South Pacific to ensure Oceania stayed a Western sphere of influence. This was the West's method for averting China from spreading its economic and military influence across the Asia Pacific region and challenging America's primacy.

It's shameful for Tonga to behave in such a way because New Zealand and Australia and also Commonwealth countries have been working very closely for Tonga for so long. With China, [it] just came in very late to the scene. I recall that maybe 10 years ago, or a little bit more than 10 years ago, Tonga goes down its diplomatic relations with Taiwan and adopted a new policy which is known in Tonga as look [to the] east policy which simply means China. That is the situation now. (Hill, 2014b).

On Radio New Zealand, Pohiva took a second swipe at discrediting Vaipulu's National Emergency Management Office. This time it was the nine day length of time the Tongan government took to organise an official request for assistance from aid donor countries and inter-government organisations such as the United Nations Development Programme. 
The whole purpose of having an emergency office is to act immediately after the disaster. But the government has been very reluctant to come in. And that really shows how inefficient and ineffective the government are in carrying out their duties to the public. (Radio New Zealand, 2014f).

Samiu Vaipulu hammered a blunt point. If the truth be known, 'Akilisi Pohiva was originally from Ha'ano Island which underwent extensive cyclone damage. At the time of his interview, Pohiva had not travelled to Ha'apai as part of the national emergency efforts carried out by government, churches, and non-government organisations. Absent from frontline relief, Vaipulu made it known that Pohiva was in no position to make participant observation comments on the ground operation.

The quickest response is from government. We were there on Sunday with tents, everything. I haven't seen $\mathrm{Mr}$ Pohiva on the scene to criticise what government has done. We have done our best and we've tried to cover the needs of the people. (Radio New Zealand, 2014e).

To prod deeper, the people's representative for Ha'apai constituency number 12, Mo'ale Finau, was a member of Pohiva's Democratic Party of the Friendly Islands. Finau had not spoken up publicly as an elected Ha'apai parliamentarian about the relief, recovery, and reconstruction needs of his electorate. In July 2012, Mo'ale's Democratic Party colleague for Ha'apai constituency number 13, 'Uliti Uata, suffered a stroke and was hospitalised. He had sought treatment overseas of which TOP $\$ 100,000$ for his medical expenses was paid for by the legislative assembly's budget. Uata had not returned to the House leaving his electorate without a parliamentarian at work for almost two years (Matangi Tonga, 2013). 
In the end, the last word went to Tonga's deputy prime minister. Despite criticism against his government for electing to do research at the wrong time - putting together a damage report rather than dialling development partners for help Vaipulu had a reply. His retort was that the state had to assess "what was needed" specifically by way of humanitarian assistance before making the call to the outside world (Television Tonga, 2014i; Radio New Zealand, 2014c; Government of Tonga, 2014c). Whether that was fair enough comment in respect that this was a category 5 cyclone, the worst of its kind, which the Tongan government tried to manage on its own for nine days was never thoroughly gauged. Vaipulu answered his critics with a tactless one-liner, the kind of reactive comeback he was publicly notorious for.

Samiu Vaipulu says the government waited nine days to request international humanitarian help because it needed to assess what the needs were. He says it did not want to abuse the trust of international development partners by asking for help when it did not know what was needed. (Radio New Zealand, 2014e).

And that was the last the public heard from the Democratic Party about their leader's dissatisfaction with Samiu Vaipulu's national operation in Ha'apai. With the opposition effectively silenced by the deputy prime minister's media retaliation it was perceivable that a contender for premier at the November ballot was Vaipulu as an alternative people's representative to Pohiva. At this stage in the 2014 election year, the parliamentary line-up for contesting the country's leadership may not have gathered enough momentum and interest to switch from the past 2010 selection.

\section{The common people}

The final analysis of disaster politics goes to Tongan journalist and political commentator Kalafi Moala. Would there be an 
abrupt or unexpected change at Tonga's 2014 general election? Given the electoral registration increase of 4,000 was predominantly twenty one year old voters and the average age for Tonga's population of 104,941 was twenty one, could the younger generation instigate the 2014 political turnaround that had been anticipated in 2010 but never quite happened? Lastly, how would the financial anxiety caused by Cyclone Ian's aftermath in Ha'apai sway the way people voted at the November poll? A paradox emerged; the one election certainty Tonga faced was uncertainty itself.

Moala was sure of one factor. When it came to taking postcyclone action it was "the common people" who were the unsung heroes the Tongan state-owned media neglected to fairly pay attention to; not the authorities and foreign donors doing the diplomatic two-step in managing disastrous political relations (Menon, 2014). But rather, the ordinary Tongans and their "incredible" generosity to give with no strings attached in spite of the over-bureaucratised hierarchy of hoops to jump through just to get containers of food and water distributed to Ha'apai families (Television Tonga, 2014m. If that was the true South Pacific the Tonga Tourism Authority marketed as the Tonga brand, then hope lay ahead. Perhaps this time in Tonga's 21 st century history, "the common people" would topple the predictably inconsolable politics which the public had grown accustomed to from four years of the Tu'ivakano administration, and indeed, vote them out (Moala, 2014a, 2014b).

I am picking up a group of Tongan registered nurses from Sydney tonight, with supplies, and they are flying out to Ha'apai in the morning to help. My niece is among them. I know of several groups of people from Tongatapu going over to help. Just as much as we need supplies, we also need skilled manpower to help with construction. 
I am impressed with the way people are helping: businesses, church to church, families to families, and just communities picking up and going over to lend a hand. This is the biggest effort of relief assistance ever given here in Tonga and from the Tongan communities overseas, and we are getting there. Things are getting restored, despite some of the hiccups which are expected, but the relief efforts cannot be defined by the failings of those in authority but rather by the incredible and self-sacrificial help given by the common people. (Moala, 2014). 


\section{References}

'Aho, L. (2014). Situation Report Number 4: National Emergency Coordination Centre (NEMO), Government of Tonga, Nuku'alofa, Tonga, January 14.

Andreou, A. (2014). Trickle-down economics is the greatest broken promise of our lifetime. The Guardian, United Kingdom, January 20. Retrieved from

http://www.theguardian.com/commentisfree/2014/jan/20/trickledown-economics-broken-promise-richest-85

Anonymous Informant 1. (2014). Personal Correspondence to Teena Brown Pulu, Tonga, January 20.

Arrow, B. (2013). Tonga loses NZ aid over use of suspect Chinese aircraft. Australian Network News, Melbourne, Australia, July 10. Retrieved from

http:/ / www.abc.net.au/news/2013-07-09/an-tonga-loses-nz-aidover-use-of-suspect-chinese-aircraft/4809676

Australia Network News. (2014a). Tonga receives $\$ 1.27 \mathrm{~m}$ insurance payout for cyclone recovery: World Bank. Australian Broadcasting Corporation: Australia Network News, January 27. Retrieved from

http:/ / www.abc.net.au/news/2014-01-27/an-tonga-awarded-firstworld-bank-catastrophe-insurance-payout/5220552

Australia Network News. (2014b). Melino Maka cited in Tongan islanders taking stock after Cyclone Ian. Australian Broadcasting Corporation: Australia Network News, January 14. Retrieved from

http://www.abc.net.au/news/2014-01-14/an-tongan-islanderstaking-stock-after-cyclone-ian-devastation/5198522

Baines, M. (2014a). Most without insurance in cyclone-hit Ha'apai. Radio New Zealand International: Dateline Pacific, Auckland, New Zealand, February 11. Retrieved from

http://www.radionz.co.nz/international/programmes/datelinepacific/ audio/2585237/most-without-insurance-in-cyclone-hit-ha'apai

Baines, M. (2014b). Tongan Government officially calls for Humanitarian Aid. Radio New Zealand International: Dateline Pacific, Auckland, New Zealand, January 22. Retrieved from

http://www.radionz.co.nz/international/programmes/datelinepacific/ audio/2582997/tongan-government-officially-calls-forhumanitarian-aid

Braddock, J. (2014). Tonga cyclone leaves thousands homeless. World Socialist Web Site, USA, January 15. Retrieved from 
http://www.wsws.org/en/articles/2014/01/15/tong-j15.html

Brant, P. (2014). China's humanitarian assistance: Signs of improvement? The Interpreter, Lowry Institute for International Policy, New South Wales Australia, January 29. Retrieved from http://www.lowyinterpreter.org/post/2014/01/29/Chinashumanitarian-assistance-Signs-of-improvement.aspx

Brown Pulu, T. (2013). Climate Change Blues: Sustaining Village Life in Tonga. Te Kaharoa: The e-Journal on Indigenous Pacific Issues, 6 (1): 260-305.

Dornan, M. (2014). Access to Electricity in Small Island Developing States of the Pacific: Issues and Challenges. Renewable and Sustainable Energy Reviews, 31: 726-735.

Ewart, R. (2014). SPREP to improve marine information library. Australian Broadcasting Corporation: Radio Australia: Pacific Beat, February 18. Retrieved from

http://www.radioaustralia.net.au/pacific/radio/program/pacificbeat/sprep-to-improve-marine-informationlibrary / 1266572?autoplay $=1266656$

Fayle, T. (2014). Tonga's finance minister sacked after defying order to quit. Australian Broadcasting Corporation: Radio Australia: Pacific Beat, Melbourne, Australia, January 9. Retrieved from

http://www.radioaustralia.net.au/international/radio/program/pacifi c-beat/tongas-finance-minister-sacked-after-defying-order-toquit/1245556?autoplay $=1245582$

Fonua, P. (2014a). Challenges for Tonga's more democratically elected government in 2014 election year. Matangi Tonga Online, Nuku'alofa, Tonga, January 17. Retrieved from

http:// matangitonga.to/2014/01/17/challenges-tonga $\%$ E2\%80\%99smde-government-2014-election-year

Fonua, P. (2014b). Cabinet supports PM's call for Finance Minister's resignation. Matangi Tonga Online, Nuku'alofa, Tonga, January 8. Retrieved from

http://matangitonga.to/2014/01/08/cabinet-supports-pms-callfinance-ministers-resignation

Gero, A., Fletcher, S., Rumsey, M., Thiessen, J., Kuruppu, N., Buchan, J., Daly, J. and Willetts, J. (2013). Disaster response and climate change in the Pacific. New South Wales, Australia: University of Technology Sydney, National Climate Change Adaptation Research Facility, Pp. 1-216. 
Government of Tonga. (2014a). Press release: Appointment of $\mathrm{Mr}$ Stuart Perry as the new General Manager for the Tonga Tourism Authority. Ministry of Commerce, Tourism and Labour, Nuku'alofa, Tonga, February 21. Retrieved from

http:/ / www.mic.gov.to/news-today/press-releases /4846appointment-of-mr-stuart-perry-as-the-new-general-manager-forthe-tonga-tourism-authority

Government of Tonga. (2014b). Press release: New Zealand Foreign Minister pays first official visit for the year to the Kingdom of Tonga. Ministry of Foreign Affairs and Trade, Nuku'alofa, Tonga, February 4. Retrieved from

http://www.mic.gov.to/news-today/press-releases/4822-newzealand-foreign-minister-pays-first-official-visito-for-the-year-tothe-kingdom-of-tonga-

Government of Tonga. (2014c). Press release: UN RC addressed Special Cabinet meeting; Government sends Appeal to donors for assistance after Cyclone Ian. Prime Minister's

Office, Nuku'alofa, Tonga, January 24. Retrieved from

http:/ / www.mic.gov.to/news-today/press-releases/4804-un-rcaddressed-special-cabinet-meeting-government-sends-appeal-todonors-for-assistance-after-cyclone-ian

Government of Tonga. (2014d). Press release: Cyclone Ian Triggers First Pacific Catastrophic Insurance Payout of USD\$1.27 Million to Government of Tonga. Ministry of Finance and National Planning, Nuku'alofa, Tonga, January 24. Retrieved from

http://www.mic.gov.to/news-today/press-releases /4802-cyclone-iantriggers-first-pacific-catastrophe-insurance-payout-of-usd-127million-to-government-of-tonga

Government of Tonga. (2014e). Press release: Tongan Prime Minister calls for international action - "Our oceans are the solution, not the problem.” Prime Minister's Office, Nuku'alofa, Tonga, January 24. Retrieved from

http:/ / www.mic.gov.to/news-today/press-releases/4800-tonganprime-minister-calls-for-international-action--our-oceans-are-thesolution-not-the-problemq

Government of Tonga. (2014f). Press release: Government acknowledges Development Partners assistance during Cyclone Ian response and recovery process. Prime Minister's Office, Nuku'alofa, Tonga, January 20. Retrieved from

http://www.mic.gov.to/news-today/press-releases /4789-governmentacknowledges-development-partners-assistance-during-cycloneian-response-and-recovery-process 
Government of Tonga. (2014g). Press release: Government of the People's Republic of China donates emergency supplies for Ha'apai. Prime Minister's Office, Nuku'alofa, Tonga, January 16. Retrieved from

http://mic.gov.to/news-today/press-releases/4776-government-ofthe-republic-of-china-donates-emergency-supplies-for-haapai

Hamilton, S. (2014). Letting down the family. Reading the Maps, Hamilton, New Zealand, January 20. Retrieved from

http://readingthemaps.blogspot.co.nz/2014/01/letting-downfamily.html

Hill, B. (2014a). Tonga relief volunteers asked to pay for delivery. Australian Broadcasting Corporation: Radio Australia: Pacific Beat, Melbourne, Australia, February 26. Retrieved from

http:/ / www.radioaustralia.net.au/international/radio/program/pacifi c-beat/tonga-relief-volunteers-asked-to-pay-for-delivery/1271620

Hill, B. (2014b). Pro China policies may alienate overseas Pacific communities. Australian Broadcasting Corporation: Radio Australia: Pacific Beat, Melbourne, Australia, January 23. Retrieved from

http:// www.radioaustralia.net.au/pacific/radio/program/pacificbeat/pro-china-policies-may-alienate-overseas-pacificcommunities / 1253018 ?autoplay $=1253004$

Hill, B. (2014c). Tonga opposition critical of government thanking only China for aid.Australian Broadcasting Corporation: Radio Australia: Pacific Beat, Melbourne, Australia, January 21. Retrieved from

http://www.radioaustralia.net.au/international/radio/program/pacifi c-beat/tonga-opposition-critical-of-government-thanking-onlychina-for-aid/1251598?autoplay $=1251616$

Hill, B. (2014d). Tongan Kiwis frustrated over Cyclone assistance. Australian Broadcasting Corporation: Radio Australia: Pacific Beat, Melbourne, Australia, January 13. Retrieved from

http:// www.radioaustralia.net.au/international/radio/program/pacifi c-beat/tongan-kiwis-frustrated-over-cyclone-assistance/1246986

Kaniva Pacific. (2014). Pacific people say National out of touch. New Zealand Kaniva Pacific, Auckland, New Zealand, February 1. Retrieved from

http:/ / www.nzkanivapacific.co.nz/2014/02/pacific-people-saynational-touch/\#.UuyfL5XNvIU

Latu, L. (2014). Facebook post to Teena Brown Pulu, Nuku'alofa, Tonga, February 28. 
Lopeti, K. (2014a). PSA fights for $22 \%$ cost of living adjustment. New Zealand Kaniva Pacific, Auckland, New Zealand, February 1. Retrieved from

http:/ / www.nzkanivapacific.co.nz/2014/02/psa-fights-22-cost-livingadjustment-2/\#.Uuyf65XNvIU

Lopeti, K. (2014b). Comment: Stop grovelling to the Chinese government. New Zealand Kaniva Pacific, Auckland, New Zealand, January 19. Retrieved from

http://www.nzkanivapacific.co.nz/2014/01/comment-stop-grovellingchinese-government/\#.Ut7IDZX2_IW

Lopeti, K. (2014c). Tu'ivakano decision baffles the Opposition. New Zealand Kaniva Pacific, Auckland, New Zealand, January 8. Retrieved from

http://www.nzkanivapacific.co.nz/2014/01/tuivakanos-decisionbaffles-the-opposition/\#.Us8rO5WIrIU

Magnall, K. (2012). Tonga - The Future. Radio New Zealand National: Insight, May $6 . \quad$ Retrieved from

http://www.radionz.co.nz/national/programmes/insight/20120506

Matangi Tonga Online. (2014a). Cyclone Ian a blessing in disguise for Tonga. Matangi Tonga Online, Nuku'alofa, Tonga, February 27. Retrieved from

http://matangitonga.to/2014/02/27/cyclone-ian-blessing-disguisetonga

Matangi Tonga Online. (2014b). China gives $\$ 600,000$ for cyclone relief. Matangi Tonga Online, Nuku'alofa, Tonga, February 12. Retrieved from

http://matangitonga.to/2014/02/12/china-gives-600000-cyclone$\underline{\text { relief }}$

Matangi Tonga Online. (2014c). Traumatized Ha'apai villages need help to prevent food shortages. Nuku'alofa, Tonga, January 29. Retrieved from

http://matangitonga.to/2014/01/29/traumatizedha\% E2\%80\%98apai-villages-need-help-prevent-food-shortages

Matangi Tonga Online. (2014d). NZ provides extra $\$ 370,000$ for cyclone response. Matangi Tonga Online, Nuku'alofa, Tonga, January 27. Retrieved from

http://matangitonga.to/2014/01/27/nz-provides-extra-370000cyclone-response

Maclellan, N. (2014). Climate Change is Wrecking the Pacific. newmatilda.com, New South Wales, Australia, January 14. Retrieved from 
https://www.newmatilda.com/2014/01/13/climate-changewrecking-pacific

McCulloch, C. (2014). Local Tongan community unhappy with NZ cyclone response. Radio New Zealand National: Morning Report, Auckland, New Zealand, January 20. Retrieved from

http://www.radionz.co.nz/national/programmes/morningreport/audi o/2582755/local-tongan-community-unhappy-with-nz-cycloneresponse

Menon, M. (2014). Humanitarianism is as culpable as war. The Hindu, Madras, India, January 10. Retrieved from

http://www.thehindu.com/opinion/interview/humanitarianism-is-asculpable-as-war/article5559462.ece

Ministry of Pacific Island Affairs. (2014). Welcome to the new Minister of Pacific Island Affairs. Ministry of Pacific Island Affairs, New Zealand Government, Wellington, New Zealand, January 24. Retrieved from

http://www.mpia.govt.nz/welcome-to-the-new-minister-of-pacificisland-affairs/

Minto, J. (2014). Key government an embarrassment after cyclone in Tonga. The Daily Blog, Auckland, New Zealand, January 19. Retrieved from

http://thedailyblog.co.nz/2014/01/19/key-government-anembarrassment-after-cyclone-in-tonga/

Moala, K. (2014a). Email Correspondence to Teena Brown Pulu, Tonga, January 20.

Moala, K. (2014b). When hope is all you have left. Pacific Politics: Political news and analysis by the Pacific Institute of Public Policy, Port Vila, Vanuatu, January 24. Retrieved from

http://pacificpolitics.com/2014/01/when-hope-is-all-you-have-left/

New Zealand Aid. (2011). New Zealand Aid Programme: Tonga - New Zealand Joint Commitment for Development. Ministry of Foreign Affairs and Trade: New Zealand Government, Wellington, New Zealand, July 13. Retrieved from

http://www.aid.govt.nz/webfm_send/112

New Zealand Government. (2014a). Murray McCully: Further Support for Tropical Ian Recovery. Beehive Govt NZ: The official website of the New Zealand Government, Wellington, New Zealand, January 24. Retrieved from

http://www.beehive.govt.nz/release/further-support-tropical-cycloneian-recovery 
New Zealand Government. (2014b). Murray McCully: NZ provides further support to cyclone-hit Tonga. Beehive Govt NZ: The official website of the New Zealand Government, Wellington, New Zealand, January 22. Retrieved from

http://www.beehive.govt.nz/release/nz-provides-further-supportcyclone-hit-tonga

New Zealand Government. (2014c). Murray McCully: More assistance to cyclone-hit Tonga. Beehive Govt NZ: The official website of the New Zealand Government, Wellington, New Zealand, January 17. Retrieved from

http://www.beehive.govt.nz/release/more-nz-assistance-cyclone-hittonga

New Zealand Government. (2014d). Murray McCully: Assistance to cyclone-hit Tonga. Beehive Govt NZ: The official website of the New Zealand Government, Wellington, New Zealand, January 12. Retrieved from

http://www.beehive.govt.nz/release/nz-assistance-cyclone-hit-tonga

New Zealand Government. (2013). Safe Travel: Official advice for New Zealanders living and travelling overseas, Ministry of Foreign Affairs and Trade, Wellington, New Zealand, December 24, Still Current. Retrieved from

https://www.safetravel.govt.nz/tonga

Northpower. (2014). Line Mechanics to Help in Tonga. Northpower, Auckland, New Zealand, January 24. Retrieved from

http://northpower.com/news/entry/line mechanics to help in tonga

Pacific Eye Witness. (2014). Tonga's Cyclone Response Plan Needs US\$12.6 Million to Implement. Pacific Eye Witness, Auckland, New Zealand, February 6. Retrieved from

http://pacificeyewitness.com/2014/02/06/tonga-govts-responseplan-praised-by-un-report-highlights-needs/

Perrottet, A. (2014). Plane stand-off between Tonga and NZ may soon be solved. Radio New Zealand International: Dateline Pacific, Auckland, New Zealand, February 26. Retrieved from

http://www.radionz.co.nz/international/programmes/datelinepacific/ audio/2587103/plane-stand-off-between-tonga-and-nz-maysoon-be-solved

Prime Minister's Office. (2014). People's Republic of China hands-over USD $\$ 600,000$ for disaster relief, Prime Minister's Office, Government of Tonga, Nuku'alofa, Tonga,February 13. Retrieved from

http:/ / www.mic.gov.to/news-today/press-releases / 4839-peoplesrepublic-of-china-hands-over-usd-600000-for-disaster-relief- 
Pulu, J. (2014). Ha'apai Rebuild. Tagata Pasifika, Television New Zealand, Auckland, New Zealand, February 14. Retrieved from

https://www.youtube.com/watch?v=4WebXc8S3FI

Radio Australia. (2014). Tonga formally asks for international cyclone recovery assistance. Australian Broadcasting Commission: Radio Australia International, Melbourne, Australia, January 22. Retrieved from

http://www.radioaustralia.net.au/international/radio/program/pacifi c-beat/tonga-formally-asks-for-international-cyclone-recoveryassistance / 1251800

Radio New Zealand. (2014a). ICAO says it has no role in Tonga/NZ MA60 controversy. Radio New Zealand International: Pacific, Auckland, New Zealand, February 26. Retrieved from

http://www.radionz.co.nz/international/pacific-news/237344/icaosays-it-has-no-role-in-tonga-nz-ma60-controversy

Radio New Zealand. (2014b). International aviation body may solve Tonga-NZ stand-off over plane. Radio New Zealand International: Pacific, Auckland, New Zealand, February 25. Retrieved from

http://www.radionz.co.nz/international/pacificnews/237229/international-aviation-body-may-solve-tonga-nzstand-off-over-plane

Radio New Zealand. (2014c). Tonga cyclone recovery plan approved by Cabinet. Radio New Zealand International: Pacific, Auckland, New Zealand, January 31. Retrieved from

http:/ / www.radionz.co.nz/news / pacific/234821/tongan-cyclonerecovery-plan-approved-by-cabinet

Radio New Zealand. (2014d). More water and shelter needed in cyclone-hit Ha'apai in Tonga. Radio New Zealand International: Pacific, Auckland, New Zealand, January 29. Retrieved from

http://www.radionz.co.nz/news/pacific/234592/more-water-andshelter-needed-in-cyclone-hit-ha'apai-in-tonga

Radio New Zealand. (2014e). Tongan govt refutes claim over slow cyclone reaction. RadioNew Zealand International: Pacific, Auckland, New Zealand, January 24. Retrieved from

http:/ / www.radionz.co.nz/international/pacificnews/234159/tongan-govt-refutes-slow-claim-over-cyclonereaction 
Radio New Zealand. (2014f). Tongan opposition critical of government cyclone response. Radio New Zealand International: Pacific, Auckland, New Zealand, January 24. Retrieved from

http://www.radionz.co.nz/international/pacificnews / 234144/tongan-opposition-critical-of-government-cycloneresponse

Radio New Zealand. (2014g). Govt Tonga response poor says Labour. Radio New Zealand News, Auckland, New Zealand, January 19. Retrieved from

http://www.radionz.co.nz/news/political/233646/govt-tongaresponse-poor-says-labour

Radio New Zealand. (2013a). Tonga's MA60 aircraft to go into service next week. Radio New Zealand International: News, Auckland, New Zealand, July 25. Retrieved from

http://www.radionz.co.nz/international/pacificnews/219729/tonga's-ma-60-aircraft-to-go-into-service-nextweek

Radio New Zealand. (2013b). Safety concerns about Tonga's new domestic aircraft. Radio New Zealand International: News, Auckland, New Zealand, July 11. Retrieved from

http://www.radionz.co.nz/international/pacific-news/220054/safetyconcerns-about-tonga's-new-domestic-aircraft

Secretariat of the Pacific Regional Environment Programme. (2013). Tonga's Deputy Prime Minister wants to merge climate and disaster functions. SPREP: Secretariat of the Pacific Regional Environment Programme, Apia, Samoa, July 11. Retrieved from

http://www.sprep.org/climate-change/tongas-deputy-prime-ministerwants-to-merge-climate-and-disaster-functions

Statistics Department Tonga. (2013). Tonga 2011 Census of Population and Housing, Volume 1: Basic Tables and Administrative Report, Statistics Department Tonga, Nuku'alofa, Tonga, Pp. 1-253.

Television New Zealand. (2014a). Tonga asks for more NZ help in Cyclone Ian aftermath. TVNZ ONE News, Auckland, New Zealand, January 17 . Retrieved from

http://tvnz.co.nz/world-news/tonga-asks-more-nz-help-in-cycloneian-aftermath-5801996

Television New Zealand. (2014b). UN report reveals extent of damage in Tonga. TVNZ ONE News, Auckland, New Zealand, January 16. Retrieved from

http://tvnz.co.nz/world-news/un-report-reveals-extent-damage-intonga-5801263 
Television Tonga. (2014a). Samiu Vaipulu, Tonga did not oppose a New Zealand expert in Television Tonga News in English, Tonga Broadcasting Commission, Nuku'alofa, Tonga, February 26.

Television Tonga. (2014b). Samiu Vaipulu, Hope for the Tongan government to start constructing transitional houses in Television Tonga News in English, Tonga Broadcasting

Commission, Nuku'alofa, Tonga, February 18. Retrieved from

https: / / www.youtube.com/watch?v=Mp2IRaFKoB8\&list=UUJsRwS1oz5i-0hNUsWU_9w\&feature $=$ c4-overview

Television Tonga. (2014c). His Excellency Mr Huang Huagnuang cited in Television Tonga News in English, Tonga Broadcasting Commission, Nuku'alofa, Tonga, February 12. Retrieved from

https://www.youtube.com/watch?v=nOhONGrtpkU\&list=UUJsRwS1oz5i-OhNUsWU_9w\&feature $=c 4$-overview

Television Tonga. (2014d). Samiu Vaipulu cited in Television Tonga News in English, Tonga Broadcasting Commission, Nuku'alofa, Tonga, February 7. Retrieved from

https: / / www.youtube.com/watch?v=AN262Cek2y0\&list=UUJsRwS1oz5i-OhNUsWU_9w

Television Tonga. (2014e). Murray McCully, New Zealand continues to stand beside Tonga and assist in any way it can cited in Television Tonga News in English, Tonga Broadcasting Commission, Nuku'alofa, Tonga, January 31. Retrieved from

https://www.youtube.com/watch?v=DKQMhtkFX2E

Television Tonga. (2014f). Saimone Helu, CEO of Tonga Water Board cited in Television Tonga News in English, Tonga Broadcasting Commission, Nuku'alofa, Tonga, January 30. Retrieved from

https: / / www.youtube.com / watch?v=UrmNUdiAuS0\&feature=c4overview\&list=UUJsR-wS1oz5i-OhNUsWU_9w

Television Tonga. (2014g). Murray McCully announces New Zealand to provide over $\$ 2$ million pa'anga assistance cited in Television Tonga News in English, Tonga Broadcasting Commission, Nuku'alofa, Tonga, January 23. Retrieved from

https: / / www.youtube.com/watch?v=3duuhg0Z51I\&feature $=c 4-$ overview\&list=UUJsR-wS1oz5i-OhNUsWU_9w

Television Tonga. (2014h). Special cabinet meeting approves reconstruction on homes cited in Television Tonga News in English, Tonga Broadcasting Commission, Nuku'alofa, Tonga. January 22. Retrieved from 
https: / / www.youtube.com/watch?v=t5OjM4TI7LE\&list=UUJsRwS1oz5i-OhNUsWU 9w

Television Tonga. (2014i). National Emergency Management Office survey cited in Television Tonga News in English, Tonga Broadcasting Commission, Nuku'alofa, Tonga, January 21. Retrieved from

https://www.youtube.com/watch?v=OziAnRsnML0\&feature=c4overview\&list=UUJsR-wS1oz5i-0hNUsWU_9w

Television Tonga. (2014j). Mark Talbot cited in Television Tonga News in English. Tonga Broadcasting Commission, Nuku'alofa, Tonga, January 17 . Retrieved from

https://www.youtube.com/watch?v=un3GN810irs\&feature $=c 4$ overview\&list=UUJsR-wS1oz5i-0hNUsWU_9w

Television Tonga. (2014k). Samiu Vaipulu cited in Television Tonga News in English. Tonga Broadcasting Commission, Nuku'alofa, Tonga, January 15. Retrieved from

https: / / www.youtube.com/watch?v=86wf5PVHYwk\&list=UUJsRwS1oz5i-OhNUsWU_9w\&feature $=c 4$-overview

Television Tonga. (20141). Samiu Vaipulu cited in Television Tonga News in English. Tonga Broadcasting Commission, Nuku'alofa, Tonga, February 7. Retrieved from

https: / / www.youtube.com/watch?v=AN262Cek2y0\&feature=c4overview\&list=UUJsR-wS1oz5i-OhNUsWU_9w

Television Tonga. (2014m). Salote Heleta Lilo cited in Television Tonga News in English. Tonga Broadcasting Commission, Nuku'alofa, Tonga, February 7. Retrieved from

https: / / www.youtube.com/watch?v=AN262Cek2y0\&feature=c4overview\&list=UUJsR-wS1oz5i-OhNUsWU 9w

Tonga Daily News. (2014). Acting PM says critical for right info to be given. Tonga Daily News, Nuku'alofa, Tonga, January 25. Retrieved from

http:/ / www.tongadailynews.to/?p=3100

Tora, I. (2014). Important to Have Ha'apai Rebuild: Vaipulu. Tonga Daily News, Nuku'alofa, Tonga, February 4. Retrieved from

http:/ / www.tongadailynews.to/?p=3322

Radio Australia. (2014). Tonga formally asks for international cyclone recovery assistance. Australian Broadcasting Corporation: Radio Australia International, Melbourne, Australia, January 22. Retrieved from 
http://www.radioaustralia.net.au/international/radio/program/pacifi c-beat/tonga-formally-asks-for-international-cyclone-recoveryassistance $/ 1251800$

United Nations. (2014a). Tonga: Tropical Cyclone Ian Situation Report No. 5 (as of 5 February 2014). United Nations Office for the Coordination of Humanitarian Affairs: Regional Office for the Pacific, Suva, Fiji, February 5. Retrieved from

http://reliefweb.int/sites/reliefweb.int/files/resources/OCHA_Tonga_ TCIan_Sitrep5_20140205.pdf

United Nations. (2014b). Tonga: Tropical Cyclone Ian Situation Report No. 3 (as of 23 January 2014). United Nations Office for the Coordination of Humanitarian Affairs: Regional Office for the Pacific, Suva, Fiji, January 23. Retrieved from

http://reliefweb.int/sites/reliefweb.int/files/resources/OCHA_Tonga TCIan_Sitrep3_20140123.pdf

United Nations Information Centre. (2014). Humanitarian Response to Cyclone Ian. United Nations Information Centre, Canberra, Australia, January 16. Retrieved from

http://un.org.au/2014/01/16/humanitarian-response-to-cycloneian-in-tonga/\#more-4033

World Bank. (2014a). Press Release: World Bank Statement on Cyclone Ian Response. The World Bank: Working for a World Free of Poverty, Sydney, Australia, February 16. Retrieved from

http://www.worldbank.org/en/news/pressrelease/2014/02/17/world-bank-statement-on-cyclone-ianresponse

World Bank. (2014b). Press Release: Tonga to Receive US \$1.27 Million Payout for Cyclone Response. The World Bank: Working for a World Free of Poverty, Sydney, Australia, January 23. Retrieved from

http://www.worldbank.org/en/news/pressrelease/2014/01/23/tonga-to-receive-payout-for-cycloneresponse

\section{Photographs}

Page 10 Lotofale'ia, South Auckland, Photograph by Teena Brown Pulu.

Page 19 Murray McCully and Lord Tu'ivakano, Photograph by Government of Tonga. 